\title{
Article
}

||||||||||||||||||||||||||||||||||

\section{Disinfection of Woodblocks of the Nguyen Dynasty of Vietnam by Low-Energy X-rays}

\author{
Nguyen Thi Thuy LinH ${ }^{1,2,}{ }^{\dagger}$, Nguyen An SoN $^{3}$, Masakazu Furuta ${ }^{1,4}$ and Tamikazu KumE ${ }^{3}$ \\ ${ }^{1}$ Department of Quantum and Radiation Technology, Graduate School of Engineering, \\ Osaka Prefecture University, \\ ${ }^{2}$ Faculty of Biology, Dalat University, \\ ${ }^{3}$ Faculty of Physics and Nuclear Engineering, Dalat University, \\ ${ }^{4}$ Research Center of Microorganism Control, Organization for Research Promotion \\ ${ }^{\dagger}$ linhntt@dlu.edu.vn
}

Received June 25, 2020

Accepted October 5, 2020

\begin{abstract}
The effects of low-energy X-ray irradiation were investigated as an intervention strategy for the disinfection of fungi-contaminated woodblocks. Fungi were isolated from the woodblocks of the Nguyen dynasty of Vietnam and Cladosporium sp. was identified as the most radiation-resistant strain in the woodblock. The dose rates of the F1 (1-mm-aluminum filtered) and F0 (non-filtered) X-rays at the surface of the woodblock were 1.14 and $4.64 \mathrm{kGy} / \mathrm{h}$, respectively. At the middle ( $8.5 \mathrm{~mm}$ from the surface) of the woodblock, the doses of the F1 and FO X-rays decreased to $76 \%$ and $20 \%$ of the surface doses, respectively. The F1 X-rays were useful for irradiating the inside of the woodblock; the concentration of the fungi at the middle decreased by more than $4 \log$ fractions at $6.2 \mathrm{kGy}$ and the fungi were eliminated with a surface dose of $8.3 \mathrm{kGy}$. Furthermore, the contaminated fungi in the woodblock were disinfected by both-side irradiation with F1 X-rays delivering a dose of $10 \mathrm{kGy}$ at a dose uniformity of 1.04 .
\end{abstract}

Key Words: low-energy X-ray, woodblock, fungi, disinfection, both-side irradiation

\section{Introduction}

Cultural heritage that is inherited from past generations is an integral part of each society and country. Inherited artefacts such as wooden structures, wooden furniture, and woodblocks are a large group of the wooden cultural heritage artefacts. Among them, woodblocks play an important role. Woodblocks, originating in China, were widely used throughout East Asia to print text, images, or patterns. Vietnamese culture is one of the oldest in Southeast Asia, and the many intangible cultural heritage of Vietnam has been presented to the world. There are more than 34,000 plates of woodblocks from the Nguyen dynasty in Vietnam with engravings in classical Chinese, as well as Chu Nom (the old Vietnamese scripts), that recorded historical and literary works during the Nguyen dynasty from the middle of the 17 th century to the beginning of the 20th century. These woodblocks are also evidence of the development of the woodblock carving and printing profession in Vietnam in that period. The woodblocks of the Nguyen dynasty of Vietnam were recognized by UNESCO and registered as a World Heritage Site in 2009. Although these woodblocks have been preserved and displayed at the National Archive Center IV (Dalat, Vietnam) since 2009, they have suffered damage by insects such as termites and 
various fungi, which is known to be the main cause of the color change and cellulose biodegradation. ${ }^{1)}$ Fungi, which can digest wood products, are the most important conspicuous organisms. Some fungi not only affect the quality of the cultural objects but are also hazardous to professionals and users, due to the production of mycotoxins. $^{2)}$

Although lime water or gas fumigation is mainly used to preserve woodblocks, ${ }^{3,4)}$ these woodblocks remain damaged by insects and fungi. These conventional methods are toxic for humans, and sometimes the disinfection effect is low. Therefore, the disinfection of fungi by an effective method is paramount for the conservation of woodblocks.

The application of radiation technologies for the preservation of cultural heritage has been widely accepted in many countries. ${ }^{5)} \gamma$-rays from ${ }^{60} \mathrm{Co}$ and electron beams/X-rays with high energy are commonly used for radiation sterilization and food irradiation. The benefits of radiation sterilization are high speed and highly efficient treatments at room temperature. However, these facilities require the installation of radiation shielding to protect personnel from high-energy radiation exposure, which is prohibitively expensive. The use of low-energy $\mathrm{X}$-rays for the sterilization of medical devices and food irradiation has lately attracted more interest. The merit of low-energy X-rays is its low shielding requirements. The irradiation device uses an X-ray tube with low energy, and is reliable, compact, and cost-effective. The compact low-energy X-ray irradiator has been widely used in healthcare for blood irradiation. In addition, compact X-ray machines can be easily transported to storage places such as museums and libraries.

This study aims to investigate the effects of lowenergy X-ray irradiation on fungi, and thus determine suitable irradiation conditions for the disinfection of woodblocks.

\section{Experimental}

\section{$2 \cdot 1$ Materials}

Woodblock samples were obtained from the National Archive Center IV (Dalat, Vietnam), from which small pieces $(\mathrm{ca} .2 \times 3 \mathrm{~cm}$ ) were used for the irradiation tests.

Standard strains of fungi, Aspergillus niger, Cladosporium cladosporioides, and Aureobasidium pullulans, were purchased from NBRC (Biological Resource Center, NITE)

HD-V2 Gafchromic film ${ }^{6}$ was purchased from Ashland, USA, and used for the dosimetry of X-rays. This film dosimeter is thin (ca. $110 \mu \mathrm{m})$, comprises an active layer $(12 \mu \mathrm{m})$ coated on a polyester substrate $(97 \mu \mathrm{m})$, and operates in a dose range of 10 to 1000 Gy

\subsection{Microbiological analysis}

The swab method was used to collect the fungi from the woodblocks. The sterile swabs were directly rubbed on the woodblock to collect fungal cells and transferred to potato dextrose agar (PDA) medium and M40Y medium (for xerophilic fungi). Chloramphenicol, a broad-spectrum antibiotic, was used in all the culture media for the inhibition of bacterial growth. Isolated fungi were identified by the morphological method. ${ }^{7)}$

The isolated fungi were incubated on PDA for 7 days at $25^{\circ} \mathrm{C}$. The conidia were harvested using phosphate-buffered saline (PBS, pH 7.0) with $0.05 \%$ Tween 80 . The conidia density was adjusted to ca. $10^{7} \mathrm{CFU} / \mathrm{mL}$ by using a disposable Optical Plastic Plankton Counter. Japanese paper $(1 \mathrm{~cm} \times 1 \mathrm{~cm}$, $0.1 \mathrm{~mm}$ ) was inoculated with $10 \mu \mathrm{L}$ of the conidia suspension $\left(10^{5} \mathrm{CFU} /\right.$ sheet $)$ and dried overnight in a biological safety cabinet at room temperature. The paper samples with fungi were inserted and sealed within a gas-permeable pouch for autoclave or EO sterilization (Hogy medical, HM1301) and subjected 
to irradiation. After irradiation, a paper sample with fungi was put in $1 \mathrm{~mL}$ PBS (pH 7.0) with $0.05 \%$ Tween 80 and vortex 20 minutes. The viability of irradiated conidia was determined using the dilution plating method with PDA. The viable cell count after the irradiation is expressed as an average $\log 10$ value with a standard deviation determined from triplicate experiments.

\section{$2 \cdot 3$ Irradiation}

X-ray irradiation system model MBR-1618R-BE (Hitachi Power Solutions, Japan) installed at the Faculty of Physics and Nuclear Engineering (Dalat University, Dalat, Vietnam) was used in this research. The irradiator can change the tube voltage (35 to $160 \mathrm{kV}$ ), tube current ( 1 to $30 \mathrm{~mA}$ ), and irradiation time or irradiation dose to emit X-rays. The irradiator was equipped with five types of filters to cut the very low energy part of the X-rays. X-rays at $160 \mathrm{kV}$, $18.6 \mathrm{~mA}(3 \mathrm{~kW})$ with no filters (F0), and a $1 \mathrm{~mm}$ aluminum filter (F1) were used in this experiment. The distance from the X-ray focal point to the sample was $150 \mathrm{~mm}$. HD-V2 film dosimeter calibrated with a Fricke dosimeter ${ }^{8)}$ was used to measure the dose rates of the X-rays. The pouches containing the paper samples with fungi were put on the surface and bottom of the woodblock samples (density: $0.71 \mathrm{~g}$ / $\mathrm{cm}^{3}$ ) as well as inserting between the samples cut into half, and irradiated for the predetermined time calculated from the dose rate.

In the case of $\gamma$ irradiation, ${ }^{60} \mathrm{Co}$ sources were used (dose rate: $1.87 \mathrm{kGy} / \mathrm{h}$ ) in the irradiation pool at the Radiation Research Center of Osaka Prefecture University, Sakai City, Japan. The dose was determined with an ion chamber (Applied Engineering Inc.) and PMMA dosimetry. ${ }^{9)}$

\section{Results and discussion}

\section{$3 \cdot 1$ Isolation of fungi from woodblock samples}

Fungi in the woodblock samples were detected

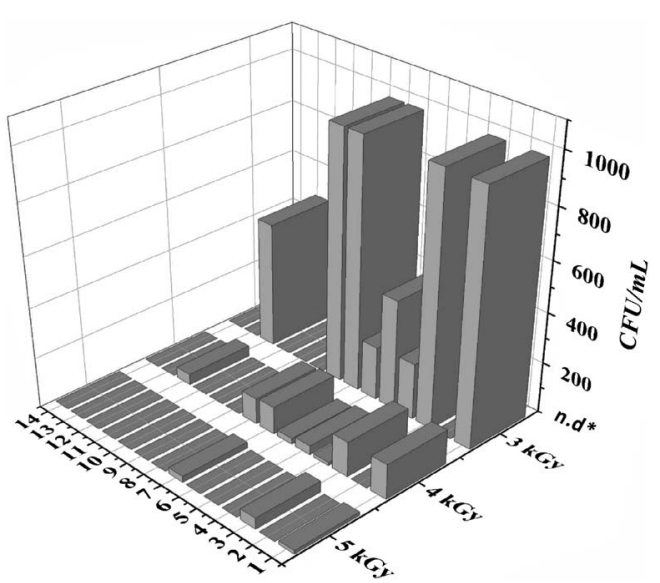

Fig. 1 Radiation sensitivity of the fungi isolated from the woodblocks. The isolated strains were labeled from VN1 to VN14. The conidia suspension $\left(10^{7} \mathrm{CFU} / \mathrm{mL}\right)$ of the 14 strains were irradiated at 3,4 , and $5 \mathrm{kGy}$ by $\gamma$ rays and $100 \mu \mathrm{L}$ irradiated sample was inoculated on PDA plate. *n.d., not detected $(<10 \mathrm{CFU} / \mathrm{mL})$.

before radiation disinfection. The deteriorating spots on the woodblocks, identified as areas of color change, were randomly chosen by the naked eye. A total of 14 fungal strains (hyphomycetes) were isolated from the woodblocks and labeled from VN1 to VN14. The isolated fungi were incubated on PDA for 7-10 days at $25^{\circ} \mathrm{C}$, and the conidia were harvested. The conidia of these 14 strains were irradiated with $\gamma$ rays at a dose range of 3 to $5 \mathrm{kGy}$ to select the strains with the highest radiation resistance. Eight strains survived at $3 \mathrm{kGy}$ irradiation, while only three strains (VN1, VN3, and VN7) survived at $5 \mathrm{kGy}$ irradiation, as shown in Fig. 1. All of these 3 strains belonged to the genus Cladosporium, based on morphology identification. The highest radiation resistant strain, VN3 (Cladosporium sp.), was selected for subsequent experiments.

\subsection{Radiation sensitivity of fungi}

The radiation sensitivities of the Cladosporium sp. isolated from the woodblock were examined by using X-rays and $\gamma$ rays. Fig. 2 shows the sur- 


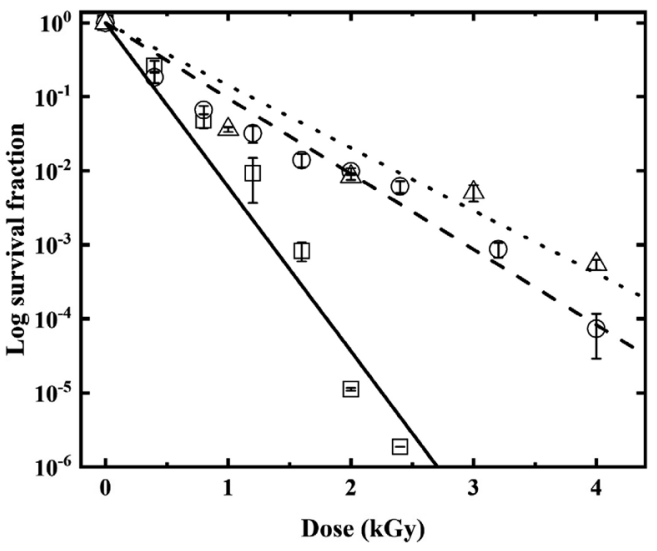

Fig. 2 Radiation sensitivity of Cladosporium sp. $\square$; F0 X-rays (non-filtered), $\bigcirc$; F1 X-rays (1-mmaluminum filtered), $\triangle ; \gamma$ rays. The conidia were dried on paper and irradiated.

vival curves of Cladosporium sp. subjected to the F0 (non-filtered) X-rays, F1 (1-mm-aluminum filtered) $\mathrm{X}$-rays, and $\gamma$ rays. The dose rates for the $\mathrm{F} 1 \mathrm{X}$-rays, F0 X-rays, and $\gamma$ rays were $1.10,4.65$, and $1.87 \mathrm{kGy} / \mathrm{h}$, respectively. All 3 survival curves of Cladosporium sp. exhibited an exponential trend. The $\mathrm{D}_{10}$ values corresponding to the $\mathrm{F} 1 \mathrm{X}$-rays, F0 $\mathrm{X}$-rays, and $\gamma$ rays were $0.79 \mathrm{kGy}, 0.57 \mathrm{kGy}$, and $0.89 \mathrm{kGy}$, respectively. The radiation sensitivity of Cladosporium sp. to the $\mathrm{F} 1 \mathrm{X}$-rays and $\gamma$ rays was similar, although it was higher in the case of the F0 $\mathrm{X}$-rays. Ha et al. ${ }^{10)}$ reported a greater reduction in Bacillus pumilus spores by X-ray irradiation with a cut-off energy of 50-150 keV. Miura et al. ${ }^{11)}$ also reported that the low energy component of the X-rays was remarkably removed by using the filter, and that the thinner filter exerted a greater effect on the cell. Further studies are necessary to clarify the effects of the low energy parts of the X-rays by using different energy and cut filters.

The radiation sensitivities of the Cladosporium sp. isolated from the woodblocks to $\gamma$ rays were compared with those of three NBRC strains (A. pullulans, C. cladosporioides, and A. niger) to better understand the radiation resistance of the isolated strains. The dry

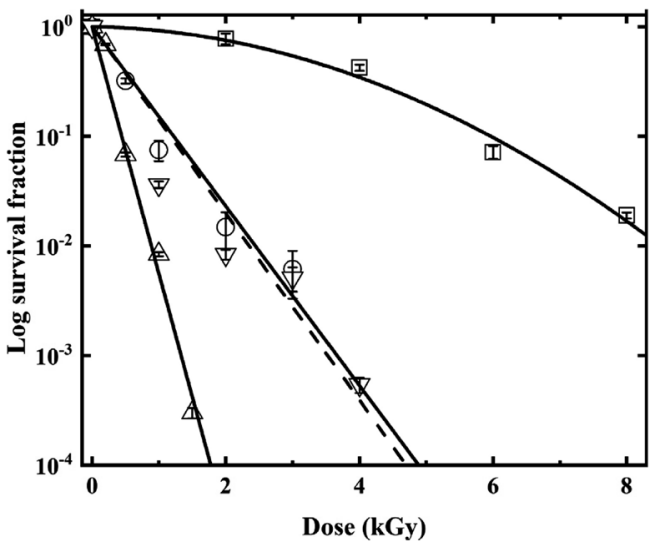

Fig. 3 Survival curves of fungi by $\gamma$ irradiation. $\square$; $A$. pullulans, $\bigcirc$; C. cladosporioides, $\triangle ;$ A. niger, $\nabla$; Cladosporium sp. (VN3). The conidia were dried on paper and irradiated.

conidia on paper were irradiated with $\gamma$ rays, and the survival curves of the 4 strains are shown in Fig. 3. Both the survival curves of Cladosporium sp. and $C$. cladosporioides show an exponential trend, and the $\mathrm{D}_{10}$ values were almost the same. A. pullulans was radioresistant with a large shoulder. Tolerance to $\gamma$ rays decreased as follows: A. pullulans $>C$. cladosporioides (Cladosporium sp.) $>A$. niger. The $\mathrm{D}_{10}$ value of $A$. pullulans was approximately 5 and 11 times as high as those of Cladosporium genus and $A$. niger, respectively. A. pullulans, a ubiquitous fungus that can be found in environments with background radioactivity, is one of the most radioresistant species because of their stress protector trehalose and melanin production. ${ }^{12)}$ These results suggest that the Cladosporium strain belongs to the medium level of radioresistant fungal species.

3.3 Decontamination of woodblock by X-ray irradiation

Woodblock samples (ca. $2 \mathrm{~cm} \times 3 \mathrm{~cm}$, thickness $17 \mathrm{~mm}$ ) were cut in half and used as a model to investigate the necessary dosage for fungal disinfection in woodblock. Table 1 shows the dose rates for the F1 X-rays and F0 X-rays at 3 positions, which are 
Table 1 Dose rates in the woodblocks of the F1 and F0 X-rays

\begin{tabular}{cccc}
\hline \multirow{2}{*}{ Position } & $\begin{array}{c}\text { Depth }(\mathrm{mm}) \text { from } \\
\text { top to bottom }\end{array}$ & \multicolumn{2}{c}{ Dose rate $(\mathrm{kGy} / \mathrm{h})$} \\
\cline { 3 - 4 } & 0 & $1.14(100 \%)$ & $\mathrm{F} 0$ \\
\hline Top & $8.5 \pm 0.8$ & $0.87(76 \%)$ & $0.94(100 \%)$ \\
Middle & $17 \pm 2.1$ & $0.65(57 \%)$ & $0.69(015)$ \\
\hline
\end{tabular}

F1: with $1 \mathrm{~mm}$ aluminum filter, F0: no filter. The percentage of the dose relative to that at the top are shown in parentheses.

Table 2 Dose distribution in the woodblocks of the F1 and F0 X-rays

\begin{tabular}{|c|c|c|c|c|c|c|c|}
\hline & \multirow{2}{*}{$\begin{array}{l}\text { Depth from top } \\
\quad(\mathrm{mm})\end{array}$} & \multicolumn{6}{|c|}{ Dose (kGy) } \\
\hline & & \multicolumn{3}{|c|}{ F0 } & \multicolumn{3}{|c|}{ F1 } \\
\hline Top & 0 & 4.0 & 7.9 & 18.5 & 4.1 & 6.2 & 8.3 \\
\hline Middle & 8.5 & 0.8 & 1.6 & 3.7 & 3.2 & 4.7 & 6.3 \\
\hline Bottom & 17 & 0.6 & 1.2 & 2.7 & 2.4 & 3.6 & 4.7 \\
\hline
\end{tabular}

F1: with $1 \mathrm{~mm}$ aluminum filter, F0: no filter

the top, middle $(8.5 \mathrm{~mm}$ depth), and bottom $(17 \mathrm{~mm}$ depth) of each woodblock. The dose rates of the F1 and F0 X-rays at the surface of the woodblock were 1.14 and $4.64 \mathrm{kGy} / \mathrm{h}$, respectively. The result indicates that approximately $75 \%$ of the low energy part of the X-rays was cut by a $1 \mathrm{~mm}$ aluminum filter. At the middle position of the woodblock, the doses of the F1 and F0 X-rays decreased to $76 \%$ and $20 \%$ of the surface doses, respectively.

Paper sheets contaminated with $10^{7} \mathrm{CFU}$ of Cladosporium $s p$. were placed at 3 positions on the woodblock and irradiated with F1 X-rays and F0 $\mathrm{X}$-rays at various doses. The paper sheet samples (thickness ca. $0.1 \mathrm{~mm}$ ) were covered by a plastic bag (thickness ca. $0.05 \mathrm{~mm}$ ) and used for irradiation in the woodblock. The doses at each position are shown in Table 2.

Fig. 4 shows the number of survivors of Cladosporium sp. in the woodblock irradiated with the F1 X-rays. At a surface dose of $4.1 \mathrm{kGy}, 1.8 \times 10^{2}$ at the

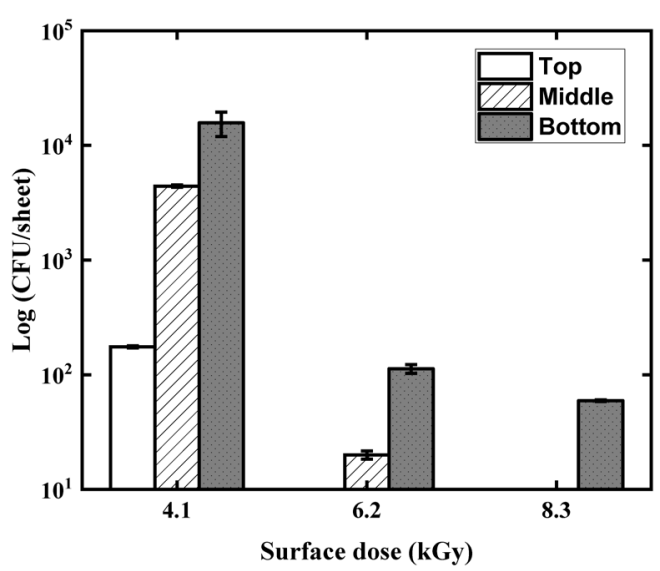

Fig. 4 Effect of 1-mm-aluminum-filtered (F1) X-rays on the Cladosporium sp. conidia in the woodblock. The effect was examined at 3 positions of the woodblock (top, middle, and bottom). Dose of each position are shown in Table 2 .

top, $4.4 \times 10^{3}$ at the middle, and $1.6 \times 10^{4} \mathrm{CFU}$ at the bottom were detected. More than $2 \log$ reduction at $4.1 \mathrm{kGy}$ and $4 \log$ reduction at $6.2 \mathrm{kGy}$ in the middle 


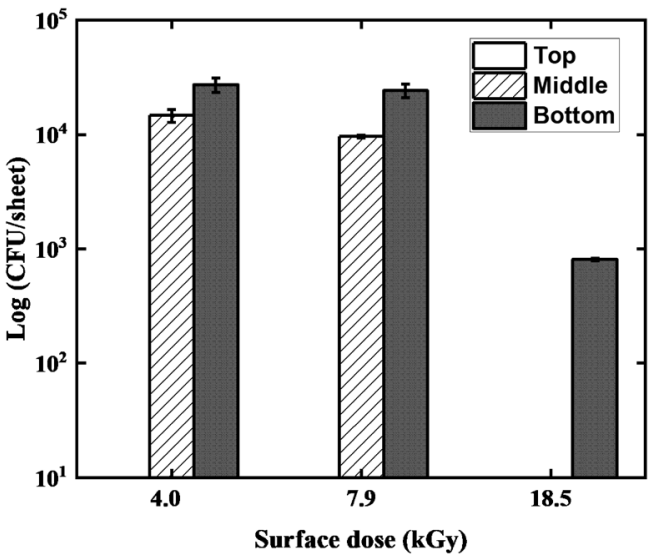

Fig. 5 Effect of the non-filtered (F0) X-rays on the Cladosporium sp. conidia in the woodblock. The effect was examined at 3 positions of the woodblock (top, middle, and bottom). Dose of each position are shown in Table 2.

of the woodblock were observed, whereas no survival conidia could be found at $8.3 \mathrm{kGy}$.

In the case of the F0 X-rays, no conidia were detected at all doses at the top of the woodblocks (Fig. 5). More than $10^{4} \mathrm{CFU}$ were detected at the middle and bottom positions of the woodblock at $4.0 \mathrm{kGy}$ and $7.9 \mathrm{kGy}$ surface irradiation. At the dose of $18.5 \mathrm{kGy}$, the number of conidia was below detection limits at the middle position.

For the disinfection of fungi in the woodblock by low-energy X-rays, both-side irradiation is necessary. In the case of $6.2 \mathrm{kGy}$ irradiation by the F1 X-rays shown in Fig. 4, more than $4 \log$ reduction was obtained in the middle of the woodblock. The doses at the surface and middle for both-side irradiation were calculated as $9.8(6.2+3.6) \mathrm{kGy}$ and 9.4 $(4.7 \times 2) \mathrm{kGy}$. The results show that more than $8 \mathrm{log}$ reduction can be obtained by both-side irradiation of the F1 X-rays at $10 \mathrm{kGy}$ with a dose uniformity 1.04 in the depth direction of woodblock.

The radiation dose required to disinfect the fungicontaminated woodblocks varied according to the fungal species, the population of the contaminants, the surface area, and the thickness of the objects. ${ }^{13)}$
The sterilization assurance level, SAL $\left(10^{-6}\right)$, is commonly used for the sterilization of medical devices, and the IAEA recommended a dose of $10 \mathrm{kGy}$ for safe sterilization of wooden artifact against fungi. ${ }^{14)}$ Moreover, the European Standard EN 113 ${ }^{15)}$ recommended doses between 25 and $50 \mathrm{kGy}$ for wood sterilization in laboratory testing procedures. In this study, the sterilization dose of the woodblock can be calculated as $9.5 \mathrm{kGy}$ by $0.79 \mathrm{kGy}\left(\mathrm{D}_{10}\right.$ value obtained in Fig. 2) $\times 12 \log$ reduction. In addition, more than $8 \log$ fractions can be reduced with bothside irradiation of $10 \mathrm{kGy}$. Considering that the contamination by fungi at the middle position of the woodblock is usually lower, it can be concluded that the necessary dose for the disinfection of fungi in the woodblock is less than $10 \mathrm{kGy}$.

Wooden cultural heritage objects are treated for insect eradication with a dose of $2 \mathrm{kGy} .{ }^{5)}$ Therefore, insects would be eradicated while the woodblock was exposed to $10 \mathrm{kGy}$ irradiation for fungal disinfection. The disinfection dose of $10 \mathrm{kGy}$ obtained in this study could also protect woodblocks from the negative effects of high dose irradiation. ${ }^{16)}$ The use of a cut-off filter for the low energy parts of the $\mathrm{X}$-rays is essential to avoid high surface doses by the $\mathrm{X}$-rays (F0).

Recently, Haff et al. ${ }^{17)}$ designed an inline system of X-ray tube-based irradiators for fruit irradiation. The merit of low-energy X-rays is its low shielding requirements and thus the design of the mobile system is recommended for the irradiation of cultural heritage objects.

\section{Acknowledgments}

We thank Mr. Nguyen Xuan Hung, Director of the National Archive Center IV (Vietnam), for providing the woodblock samples. We also thank Ms. Pham Thi Ngoc Ha, Mr. Nguyen Dang Trong Phuc, and Mr. Cao Van Hai of the Faculty of Physics and Nuclear Engineering, Dalat University, Vietnam for 
their support on X-ray irradiation and dosimetry.

\section{References}

1) Severiano, L. C., Lahr, F. A. R., Bardi, M. A. G., Santos, A. C., et al., Influence of gamma radiation on properties of common Brazilian wood species used in artwork, Prog. Nucl. Energy, 52, 730-734 (2010)

2) Nielsen, K. F., Mycotoxin production by indoor molds, Fungal Genet. Rep., 39, 103-117 (2003)

3) Luong, H. Q., Building woodblocks preservation system based on the community. Preservation of Woodblocks in Asia: Sharing Experiences, 19-36 (2017)

4) Havermans, J. B. G., Introduction: Uses of ionizing radiation for tangible cultural heritage conservation, IAEA, 1-16 (2017)

5) Katusin-Razem, B., Braun, M., Razem, D., Mihalijevic, B., et al., The state of the art in radiation processing for cultural heritage in Croatia: Uses of ionizing radiation for tangible cultural heritage conservation, IAEA, 121-128 (2017)

6) Agematsu, T., Hanaya, H. and Kojima, T., Easy measurement system for two dimensional relative dose distribution of ion beam using Gaf-chromic film and image scanner, Radioisotopes, 57, 87-98 (2008)

7) Samson, R. A., Houbraken, J., Thrane, U., Frisvad, J. C., et al., Food and Indoor Fungi: CBS Lab. Man. Ser., Second ed., Centraalbureau voor Schimmelcultures, 375-377 (2010)

8) Kume, T., Tachibana, H. and Takehisa, M., Fricke dosimetry in low dose range for food irradiation, JAERI-M, 82-100, Japan Atomic Energy Research Institute (1982)

9) Yamamoto, T., Ohnishi, T., Kanazawa, T., Oka- moto, S., et al., Dose rate determination of a high ${ }^{60} \mathrm{Co} \gamma$-Ray field $\left(3.7\left(\mathrm{kC} \mathrm{kg}^{-1}\right) / \mathrm{h}\right)$, Radioisotopes, 36, 129-132 (1987)

10) Ha, T. M. H., Yong, D., Lee, E. M. Y., Kumar, P., et al., Activation and inactivation of Bacillus pumilus spores by kiloelectron volt X-ray irradiation, PLoS One, 12, 1-15 (2017)

11) Miura, M., Morita, N. and Hakkim, F. L., Quality control of X-ray irradiator by biological markers, Jpn. J. Radiat. Saf. Manage., 10, 33-39 (2011)

12) Saleh, Y. G., Mayo, M. S. and Ahearn, D. G., Resistance of some common fungi to gamma irradiation, Appl. Environ. Microbiol., 54, 2134-2135 (1988)

13) Sengupta, B., Medlin, D., Sprunk, M., Napolitano, J., et al., X-ray cabinet to deliver highly characterized low-dose soft X-ray radiation to biological samples, Rev. Sci. Instrum., 91, 034104 (2020)

14) Ponta, C., Havermans, J. B. G. and Boutaine, J., Disinfection of cultural heritage artefacts using irradiation: Uses of ionizing radiation for tangible cultural heritage conservation, IAEA, 93-103 (2017)

15) European standard EN 113 (CEN 96), Wood preservatives-Test method for determining the protective effectiveness against wood destroying basidiomycetes-Determination of toxic values. European Committee for Standardization (1997)

16) Kalawate, A. and Mehetre, S., Isolation and characterization of mold fungi and insects infecting sawmill wood, and their inhibition by gamma radiation, $R a$ diat. Phys. Chem., 117, 191-197 (2015)

17) Haff, R., Jackson, E., Gomez, J., Light, D., et al., Building lab-scale X-ray tube based irradiators, $R a$ diat. Phys. Chem., 121, 43-49 (2016) 


\title{
低エネルギー X 線によるベトナム阮朝の版木の殺菌
}

\author{
Nguyen Thi Thuy Linh ${ }^{1,2, \dagger}$, Nguyen An $\operatorname{Son}^{3}$, 古田雅一 ${ }^{1,4}$, 久米民和 ${ }^{3}$ \\ 1 大阪府立大学大学院工学研究科 · 量子放射線系専攻, \\ 2 ダラット大学生物学部, \\ 3 ダラット大学物理・原子力工学部, \\ 4 大阪府立大学地域連携研究機構・放射線研究センター \\ ${ }^{\dagger}$ linhntt@dlu.edu.vn \\ 2020 年 6 月 25 日 受付 \\ 2020 年 10 月 5 日 受理
}

文化財である版木の污染カビについて，低エネルギーX 線による殺菌効果を検討した。ベトナ ム阮王朝の版木から分離されたカビの中で，最も放射線抵抗性の株はCladosporium sp. であった。 用いたX線 F1（1 mm アルミニウム フィルター装着）と F0 (フィルターなし) の版木表面にお ける線量率は, 1.14 及び $4.64 \mathrm{kGy} / \mathrm{h}$ であった。版木の中心部 (表面からの深さ $8.5 \mathrm{~mm}$ ) の線量は, 表面線量に対し F1 で76\%, F0 で20\%に減少した。F1は深部の照射に適しており, 版木中心部の カビは表面 $6.2 \mathrm{kGy}$ の照射で 4 桁減少し, $8.3 \mathrm{kGy}$ で検出されなくなった。これらの結果から, 版木 中の污染カビはX線（F1）を用いた両面照射により, 線量 $10 \mathrm{kGy}$, 線量均一度 1.04 で効果的な殺 菌が可能であることが示された。 